\title{
Masculinities in Traffic: Identity Processes of Motorcycle Deliverymen in Belo Horizonte, Brazil
}

\author{
Gregório Ribeiro de Miranda ${ }^{1, *}$ \\ Orcid.org/0000-0003-1965-4226 \\ Adriano Roberto Afonso do Nascimento ${ }^{1}$ \\ Orcid.org/0000-0002-7752-0114
}

${ }^{1}$ Universidade Federal de Minas Gerais, Belo Horizonte, MG, Brasil

\begin{abstract}
Motorcycle deliverymen/couriers share a significant part of the blame for the upsurge in traffic accidents and mortality rates in Brazil, and they exhibit the same general profile that other Brazilian motorcyclists exhibit: low-income males. Based on Social Identity Theory, the present study seeks to identify and investigate both the manner in which motorcycle deliverymen in Belo Horizonte (Minas Gerais, Brazil) perceive the various conceptions of masculinity and the way in which such conceptions potentially correlate with how such bikers view themselves, feel and behave as motorcyclists. In order to achieve the above objectives, we conducted ten semi-structured interviews with motorcycle couriers living in Belo Horizonte, analyzing the interviews via the content analysis method. Those interviewed revealed that they share a common ideal replete with male values: a guy that is competent, responsible, heterosexual, daring, fearless, independent and dominant. Although the men interviewed recognize that they face many traffic risks, they largely consider themselves invulnerable to such risks. A good biker is not merely a good driver and a hard worker, but also an exceptional man.
\end{abstract}

Keywords: Masculinity, social identity, motorcycle deliverymen.

\section{Masculinidades em Trânsito: Processos Identitários de Motoboys em Belo Horizonte - MG}

\section{Resumo}

Os motoboys têm participação significativa na elevação das taxas de acidente e mortalidade no trânsito e compartilham do perfil geral de motociclistas no país: são homens de baixa renda. O presente trabalho, baseado na Teoria da Identidade Social, teve como objetivo identificar e analisar como motoboys de Belo Horizonte/MG concebem diferentes versões de masculinidade e que relações essas podem manter com a forma como se veem, se sentem e se comportam como motociclistas. Para tanto, realizou-se dez entrevistas semiestruturadas com motoboys moradores de Belo Horizonte, que foram analisadas através da técnica de análise de conteúdo. Os entrevistados demonstraram compartilhar de um ideal permeado

Mailing address: Rua Lagoa Santa, 253, Bairro Carlos Prates, Belo Horizonte, MG, Brazil 30.710-090. E-mail: gribmir@gmail.com

O artigo é parte da dissertação de mestrado do primeiro autor, com apoio financeiro da Fundação de Amparo à

Pesquisa do Estado de Minas Gerais (FAPEMIG), sob orientação do segundo autor. 
por valores masculinos: um sujeito competente, responsável, heterossexual, ousado, destemido, independente e dominante. Apesar de reconhecerem conviver com muitos riscos no trânsito, os entrevistados em grande medida se julgam invulneráveis a eles. O bom motoqueiro não é apenas um bom condutor e bom trabalhador, é um homem excepcional.

Palavras-chave: Masculinidade, identidade social, motoboys.

\section{Masculinidades en Tránsito: Procesos Identitarios de Motomensajeros en Belo Horizonte - MG}

\section{Resumen}

Los motomensajeros tienen participación significativa en la elevación de las tasas de accidente y mortalidad en el tráfico y comparten del perfil general de motociclistas en el país: son hombres de baja rienda. El presente trabajo, basado en la Teoría de la Identidad Social, tubo como objetivo identificar y analizar como motomensajeros de Belo Horizonte/MG conciben diferentes versiones de masculinidad y cómo esas interactúan con la forma cómo se ven, se sienten y se comportan como motociclistas. Para tanto, se realizaron diez entrevistas semi-estructuradas con motomensajeros residentes en Belo Horizonte, que fueron analizadas a través de la técnica de Análisis de Contenido. Los entrevistados demostraron compartir de un ideal permeado por valores masculinos: un sujeto competente, responsable, heterosexual, osado, valiente, independente y dominante. Aunque reconozcan convivir con muchos riesgos en el tráfico, los entrevistados en gran medida se juzgan invulnerables a ellos. El buen motociclista no es solamente un buen conductor y buen trabajador, es un hombre excepcional.

Palabras clave: Masculinidad, identidad social, motomensajeros.

Historically recent and still growing strongly, the popularization of cars and the motorcycle boom in our cities have led to significant changes in our day-to-day lives and have been assimilated in diverse ways by the populace. More than a mere means of transportation, vehicles have become an income source for many individuals and an essential part of life for others. Professional motorcyclists are situated halfway between these two possibilities, daily risking their lives to meet the growing demand for delivery services. Within this context, the individuals who have most enjoyed the benefits of motorization have been men; on the other hand, they have also suffered its negative consequences the most.

Abridged by Waiselfisz (2013), the records of Brazil's Mortality Information System (SIM, acronym in Portuguese) reveal that the total number of traffic-related fatalities in Brazil went from 28,995 per year in 2000 to 43,256 in 2011, a 49.2\% increase in 11 years. Nevertheless, the increase both in Brazil's fleet of motor vehicles and in its traffic death rate did not occur symmetrically among the various transportation means in Brazil. Although culturally overrated and considered an essential part of contemporary life, cars still are a difficultly acquired consumer good for most Brazilians, who have increasingly opted for motorcycles as a means of transportation in the last decade.

From 1996 to 2010, while Brazil's car fleet increased $133.5 \%$, its motorcycle fleet grew by $491.1 \%$ (Waiselfisz, 2013). According to Waiselfisz, the variation in mortality rates was even more contrasting, increasing $87.5 \%$ for car drivers and $610 \%$ for motorcyclists during the same period. In summary, factors such as "(i) the weak appeal of public transportation, (ii) the low cost of motorcycles, and (iii) their facility to get through traffic jams in major metropolitan areas" (Ferreira, 2009, p. 15) appear to outweigh the huge risk related to riding motorcycles.

Just as the number of traffic accident fatalities is not the same for different means of transportation, its distribution across the population is also disparate. Among the various 
potential observations that could be made in this respect, one stands out: Highway deaths are predominantly male. In 2011, no less than $82.3 \%$ of the fatal traffic-accident victims in Brazil were men (Waiselfisz, 2013). In addition to the fact that motorcyclists exhibit the highest highway fatality rate, they also display one of the death rates with the highest ratio of male victims, amounting to $89.7 \%$ for the same year. Waiselfisz also reported that bikers are the youngest universe, with an average age of 32.3 years, and are members of the poorest households.

\section{Traffic and Gender}

Although widely evidenced in the literature, the gender dimension is one of the facets that are neglected in the field of research concerning highway traffic. The majority of the research that has been conducted has sought to explain or comprehend traffic by way of presuming an anonymous, genderless driver lacking social relationships. It is perhaps because male vulnerability on the road was considered a natural fact or the result of external causes that such research has been more or less limited to describing men's rates of motorization and mortality.

Nonetheless, several Brazilian studies have attempted to grasp the constructions of gender that abound in the context of traffic. Studies conducted by Figliuzzi (2008) and by Lara (2007), for example, revealed that different facets of the same object - the car - are emphasized depending upon the gender with which one associates the object. Furthermore, they corroborated the observation that both cars and women, regardless of the methodological approach, are subjected to the male perspective. As a general rule, the car fits into our social framework as an object of male consumption.

A study conducted by Souza (2001) presented the innovative feature of also examining the way in which young women conceive the car, what meanings they attribute to it and what uses they make of it. The author revealed that men and women focus on different elements of the same representation, concluding that risky beha- vior in traffic is more highly valued and thus more common among young men.

Meanwhile, the international literature on the subject boasts studies that have sought to explain the relationship between gender, the city and cars. Virginia Scharff (1992) showed, for example, how car manufacturers' gender notions have even defined the most basic characteristics of cars, influencing the manner in which cars have been used and the consequences of their use. Scharff claimed that innovations aimed at improving car safety, comfort and cleanliness have historically been considered concessions to female frailty, even when they were useful and important for all drivers and passengers.

Analyzing the emergence and justificatory function of the negative, "woman driver" stereotype, Berger (1992) contended that the onset of World War I took American men away from their homes, but left their cars behind, producing the ideal conditions for women to learn to drive. Nonetheless, the possibility of women taking possession of the cars would have been viewed with concern by men, who feared that women, with their newly acquired freedom, would reject their husbands, children and homes.

On the other hand, Wachs (1992) stressed the central role of the car and mobility in the origin and perpetuation of an urban realm split into two spheres: male and female. Wachs claimed that, traditionally, while attributing masculine traits - such as assertiveness, economic activity and intellectual creativity - to the cities, we associate the suburbs with the female sphere, domesticity, passiveness, restfulness, closeness to nature, and spiritual values.

Referring to Mexico, (1998) Keijzer stated that the same attributes, values, functions and behaviors that a culture presumes essential to men, and which represent evident advantages over women, end up resulting in great harm to the health of such men (and of other men, women and children as well) as time passes and such values become stereotypical. In this sense, Keijzer was correct when he suggested that male socialization is a factor that accounts for excessive male mortality, with transit being one of the major causes of death. 
As a whole, such studies examined the correlations between gender, mobility, violence on the road and the day-to-day context, as well as their consequences, identifying a substantial difference between men's and women's experiences in relation to accessing the city and being exposed to risks. Other studies focus on specific groups that consider the motorcycle an essential part of their identity and that predominantly consist of men: motorcycle clubs and professional motorcyclists.

\section{Masculinities on Two Wheels}

Notwithstanding the challenge they pose as an object of research because of their alienation of, suspicion of and occasional hostility toward non-members, North American motorcycle clubs have been the object of abundant longitudinal studies (Hopper \& Moore 1983, 1990; Wolf, 1991). On the whole, such surveys revealed that their participants share a "love" for motorcycles, a strong sense of brotherhood that differentiates them from other bikers and a general feeling of not belonging to conventional society.

American biker clubs are predominantly composed of men between the ages of 21 and 45 years, with little formal education and practically no racial diversity (Hopper \& Moore, 1983). Furthermore, Wolf (1991) discovered that most club members come from the lower working classes. To Wolf, such men's attraction to outlaw motorcycle gangs can be explained by the unique opportunity such gangs offer them to develop a personal identity that is valued and is considered genuine.

In spite of the power and the impact of the women's liberation movement between the 1960s and the 1980s, Wolf claimed that biker gang members' depreciative attitudes toward women remained unaltered. On the other hand, Hopper and Moore (1990) argued that noteworthy changes did in fact occur during that period. According to them, the subordination of women in motorcycle clubs actually increased: Over the years, women, who have always been reduced to sex objects, have been, in the authors' opinion, increasingly viewed as workers who are responsible for earning money for the biker club, prin- cipally as nightclub dancers, but also as prostitutes or ordinary employees.

Brazilian motorcycle clubs exhibit both similarities and differences in relation to their North American counterparts. For the most part, the studies we checked reveal a similar predominance of men, yet, in Brazil, such men enjoy greater purchasing power. With respect to bikers from the city of Rio de Janeiro, Luz (2009) observed the motorcycle's centrality not only in the biker-club environment, but also in each biker's personal life. According to the bikers interviewed, motorcycling figures as a way of life that one neither choses nor abandons, a lifestyle that is inherent to one's destiny and that is present from childhood to death. To them, a "true biker" is one who loves his motorcycle and demonstrates that he has a protective, manly, emotional relationship with it. Through his zeal, loving care and jealousy, such a man would purportedly be interacting with a feminized object: the motorcycle, such a pretty, delicate, defenseless companion. Nonetheless, the motorcycle club members the author interviewed were resistant to the notion of gangs, basing themselves on the ideal of a motorcyclist opposed to violence, guided by rules and supportive of the needy.

In Salvador (Brazil), Fernandes (2012) came across biker groups that are open to interaction with non-members and supportive of solidarity campaigns. Nonetheless, other groups of motorcyclists exhibited an exclusive, discriminatory attitude, discouraging conversations with strangers to the group. According to Fernandes, the only common denominator between such different groups was (once again) their "passion" for motorcycles.

However, considering the population as a whole, one has to admit that the majority of Brazilian bikers lack the financial conditions necessary to invest in powerful, impressive motorcycles, nor can they afford the high customization costs and the countless accessories. For such motorcyclists, their relationship with the motorcycle is put into practice through paid activities. In view of the car-saturated highway system, the most competitive, quickest and cheapest way of satisfying the great demand for delivery services has been to use motorcycles (Ferreira, 2009; 
Matos, 2008; Paes-Machado \& Riccio-Oliveira, 2009; Silva, Andrade, Soares, Nunes \& Melchior, 2008).

More commonly referred to as motoboys ("motorcycle delivery boys") or motofretistas ("motorcycle couriers") in Brazilian Portuguese, professional motorbikers in many Brazilian cities form the majority of the motorcycle universe (Ferreira, 2009). Motoboys also contribute significantly to increasing the number of traffic accidents and the highway mortality rates. In the city of Belo Horizonte, $55.5 \%$ of the victims who reported that they were working at the time of the accident were motorcyclists (Rodrigues, Ladeira, Pereira, \& Paula, 2005). Similar situations exist in other Brazilian cities, such as São Paulo (Matos, 2008) and Porto Alegre (Ferreira, 2009).

In addition, the motoboy category runs even more risks due to a chronic lack of safety, it being an attractive target for robberies and assaults (Paes-Machado \& Riccio-Oliveira, 2009). Nevertheless, while the lack of police protection is a risk factor, the police's abuse of authority in relation to motorcycle deliverymen also is. The authors correlate this fact with the stigmatization suffered by such professionals, who are constantly associated with violent crime and drug trafficking. Castro (2010) discovered that, along with the discrimination they suffer, such workers also have to cope with the substandard working conditions and high risk of the occupation. They would thus be prone to mental health problems and it would be difficult for them to enjoy a sense of fulfillment in their line of work, sticking to it merely as a form of subsistence. Moreover, Diniz, Assunção, and Lima (2005) affirmed that intolerance toward motorcycle deliverymen is practiced not only by civil society, but also by researchers themselves, when they base their explanations of motoboys' work accidents on a "dangerous activity" ideology. Researchers taking such a stance would be blaming motorcyclists for engaging in a hazardous activity, describing such behavior as "imprudence," "audacity," "recklessness," "incivility," "thrill seeking," etc. (p. 906).

Irrespective of the wide range of research approaches employed, one issue is common to all research focusing on professional motorcyclists: Despite the risks and precariousness, why do so many individuals still choose this profession? As aforementioned, financial motives are among the principal reasons for which people get into this line of work. Hiring in the sector of delivery services began to boom, attracting cheap labor, especially undereducated, previously unemployed males (Ferreira, 2009; Matos, 2008; Paes-Machado \& Riccio-Oliveira, 2009; Silva et al., 2008).

Problematizing the notion that such men, by reason of their socioeconomic status, join the profession merely for lack of other job opportunities, Castro (2010) contended that "many motorcycle lovers join the profession because it offers them the chance to continue doing what they most enjoy in life: riding a motorcycle and earning a living" (p. 161). They would thus be active subjects in relation to their choices and their assumption of both the occupation and motorcycling. Yet, why is it that men, and not women, with low incomes accept facing motorcycle-delivery risks in exchange for pay and the "enjoyment of riding"? At this point, we are convinced we have enough evidence to affirm that the social construction of masculinities can be an important factor that contributes to determining the practices of motorcycle deliverymen and motorcyclists in general.

\section{Masculine Identities}

Examining the professional motorcyclist's situation, we come face-to-face with an imbricate relationship between two universes: motorcycling and manliness. Nevertheless, the first point we must acknowledge is that this meeting of universes is configured not only objectively, but also as a masculinized subjective space.

Apparently, it is not by accident that the traits that make up the negative motoboy stereotype described by Diniz et al. (2005) - "imprudence," "audacity," "recklessness," "incivility," "thrill seeking" - coincide so closely with values and behaviors historically associated with masculinity (Connell, 1997; Keijzer, 1998; Kimmel, 1998; Olavarría, 2004). Similarly, we believe it is by now evident that the ties of brotherhood 
that are established to varying degrees among motorcycle club members have a common denominator: They are bonds of cooperation between brothers, i.e., between men. The motorcycling universe is full of groups of men who consider the motorcycle an essential part of their identity.

Contrary to what we would be led to believe under the dangerous-activity perspective, which is essential to the establishment of Traffic Psychology and the implementation of a psychological assessment system for drivers in Brazil (Diniz et al., 2005; Silva \& Günther, 2009), one possible hypothesis is that individuals' driving behavior is not influenced by their idiosyncrasies, personalities and psychobiological tendencies alone, but also by their membership in social groups that exceed them and of which they feel they are a part.

Such assumptions, which are not completely unrelated to various studies cited above, were specifically systematized by Henri Tajfel $(1982,1983)$ in his Social Identity Theory (Amâncio, 1997; Deschamps \& Moliner, 2009). The theory's relevance resides in the fact that it enables us to conceptually operationalize the connection between the realms of psychology and sociology, that is, the relationship between one's self and one's perception of belonging to a group.

Tajfel (1983) defined social identity as "the portion of an individual's self-concept that derives from his sense of belonging to a social group (or groups), along with the emotional and value-based significance associated with such belonging" (p. 290). It thus involves one, two or all three of the following elements: cognitive, or awareness of belonging; evaluative, or a positive or negative assessment of the group and/or of one's belonging to the group; and an emotional investment in the group itself or in groups with which one perceives one has a relationship.

Identity is thus not what one "is" or something that one "has" in a stable manner, but rather "a subjective, dynamic phenomenon that results from a two-pronged observation of the similarities and differences between oneself, other people and certain groups "(Deschamps \& Moliner, 2009, p. 14). In this manner, social ac- tors are part of a social sphere not only through their awareness of belonging, but also by way of the fact that, upon recognizing that they are similar, they seek to situate themselves in a specific position, distinguishing themselves from groups they do not belong to, while also differentiating themselves in a personally distinct manner (Deschamps \& Moliner, 2009; Tajfel, 1982, 1983). Deliberately vague and flexible according to Tajfel (1983), the notion of identity is useful to us inasmuch as it enables us to conduct integrated research focusing both on people's membership in groups that enjoy face-to-face interactions (which is the case of motorcycle deliverymen) and on people's affiliations with broader social categories (in the present case, motorcyclists and the male sex).

Individuals thus construct their identities based on their sense of being different in a social universe that is subdivided into groups, some of which they feel they belong to; and others from which they feel they differentiate themselves. In other words, the components of social identity, among which one observes similarities and differences, are inseparable (Deschamps \& Moliner, 2009), or interdependent, acquiring meaning by way of social comparison (Amâncio, 1997).

Nonetheless, when social actors enjoy interdependent relationships, such interdependence does not necessarily occur symmetrically (Amâncio, 1997; Deschamps \& Moliner, 2009). In intersex relationships, for example, the gender differentiation and the historically formed consensus as to sexual stereotypes come about in a clearly asymmetrical manner (Amâncio, 1997).

In terms of our objectives, however, beyond merely recognizing that asymmetry exists between men and women, we are especially interested in comprehending, within the masculine universe itself, the manner in which the relationships between the categories that internally make up this universe come about, that is, the relationships between different versions of masculinity (Kimmel, 1998). According to Keijzer (1998), after all, it is essential for us to also "analyze how we create relationships of power and domination among men" (p. 209, author's translation) 
Furthermore, becoming a man involves a series of pressures and limits on a man's possibilities of self-knowledge, self-care and interaction with other men and women (Keijzer, 1998; Kimmel, 1998; Olavarría, 2004). "In order to become real adults, men are expected to subject themselves to "orthopedic treatment"; being a man requires learning. It's a hard road, but it has its rewards “(Olavarría, 2004, p. 237, author's translation).

Focusing on male motorcyclists, the present study seeks to contribute to understanding the social construction of the high rate of motorization and mortality among men in general and particularly among professional motorcyclists. Along these lines, we sought to identify and explore both the manner in which motorcycle deliverymen in the city of Belo Horizonte (Minas Gerais, Brazil) conceive different versions of masculinity and the correlations such versions can have with the way motoboys perceive themselves, feel and behave as motorcyclists.

\section{Method}

The present research is a qualitative study of an exploratory nature.

\section{Participants}

Aiming at achieving our research objectives, between April and June 2015, we conducted ten interviews with motorcycle deliverymen living in the city of Belo Horizonte (Minas Gerais, Brazil). We chose participants that were interested in our study and willing to participate in it, contacting them via snowball sampling, whereby each participant indicated other individuals that were potentially interested in participating in the study.

Exclusively male, the participants formed a heterogeneous group featuring different types of occupational activities and categories (Table 1). The interviewees' ages ranged between 27 and 50 years, and the length of their careers as motorcycle couriers varied from 2 to 19 years. Their answers to the questionnaires revealed that they had between 2 and 36 years of experience as motorcyclists. Six of them reported that motorcycle delivery was their only income source; two of them stated they were working as motoboys in two shifts; and two of them reported that they had another steady job. Only three of them said they were single. The names employed to refer to the interviewees are fictitious.

Table 1

Profile of the Interviewees

\begin{tabular}{|c|c|c|c|c|c|}
\hline Interviewee & Age & $\begin{array}{c}\text { Experience } \\
\text { as a motorcyclist }\end{array}$ & $\begin{array}{c}\text { Experience } \\
\text { as a motorcycle } \\
\text { deliveryman }\end{array}$ & $\begin{array}{l}\text { Other } \\
\text { job }\end{array}$ & $\begin{array}{c}\text { Marital } \\
\text { status }\end{array}$ \\
\hline Davi & 40 years & 22 years & 18 years & Yes & Married \\
\hline Gustavo & 30 years & 18 years & 4 years & Yes* & Married \\
\hline Jorge & 43 years & 35 years & 6 years & No & Married \\
\hline Lucas & 29 years & 17 years & 8 years & No & Single \\
\hline Marcos & 32 years & 2 years +7 months & 2 years, 6 months & Yes & Married \\
\hline Natan & 30 years & 9 years +3 months & 9 years & Yes* & Married \\
\hline Nicolas & 50 years & 36 years & 19 years & No & Married \\
\hline Nelson & 26 years & 8 years & 2 years & No & Single \\
\hline Renan & 40 years & 26 years & 15 years & No & Single \\
\hline Renato & 27 years & 14 years & 7 years & No & Married \\
\hline
\end{tabular}

Note: *holds two jobs as a motorcycle deliveryman/courier. 


\section{Instruments}

We chose both to conduct semi-structured interviews, because we consider their versatility convenient, and, at the same time, to minimally guide the interviewees' answers so as to ensure the comparability of the answers. The interview script featured nine questions, and it sought to assess the manner in which the interviewees represent and evaluate themselves, the groups they belong to and groups of which they are not members: 1 . How do you prefer to be called, motorcyclist or biker? Motorcycle deliveryman or motorcycle courier? Why? 2. Do you often hear that motorcyclists enjoy a special kind of affiliation among themselves? Is it true? 3. How do you identify a good motorcyclist? Why? 4. How do you identify a bad motorcyclist? Why? 5. Do you consider yourself a good motorcyclist? Why? 6. How do other drivers behave in relation to you in traffic? 7. Do you notice any difference between motorcycle deliverymen and other motorcyclists? What differences? 8. How is the relationship between them? 9. Have you witnessed many accidents? Why do you think they happen?

\section{Procedures}

Data Collection. Having obtained the participants' consent, the same researcher conducted, digitally recorded and later transcribed the interviews, so as to ensure the most accurate interview-transcriptions possible. Furthermore, the transcription work itself enabled us to formulate our first impressions and assumptions, which proved to be useful during the text-coding phase.

Data Analysis. Subsequent to being transcribed, the interviews were analyzed using the thematic content analysis approach (Bardin, 1977/2011), aided by Nvivo7 software. With respect to coding and interpreting the content of the interviews, we opted for enumerating the number of sources in which each set of meanings manifested itself and presenting them in the results section. The approach was worthwhile to the extent that it made it possible for us to perform, by way of a thorough analysis of the transcriptions, a systematic restructuring of the text, which facilitated our identification of the psycho-sociological processes involved in the interviewees' constructions of meanings.

\section{Ethical Procedures}

The present study was approved by the Research Ethics Committee of the Federal University of Minas Gerais by way of ruling no. 648,350 (April 16, 2014). All of the examinees participated voluntarily, having signed an informed consent form.

\section{Results and Discussion}

The content analysis of the interviews produced a total of twenty-two codes, classified into four categories: Professional Motorcyclists, Amateur Motorcyclists, Motorists and Regulatory Authorities (Figure 1). In light of the qualitative nature of the present study and of the data obtained, we provide a theoretically oriented presentation of the results below.

\section{Us: Professional Motorcyclists and Amateur Motorcyclists}

To the interviewees, motorcycling and career are two closely related spheres that are mutually intertwined and are often confused. Whether in terms of the course taken in the profession or in the manner in which motorcycling and career are named and are identified with each other, the boundary between leisure and work is often tenuous. At certain moments, however, these are precisely the two extremes that differentiate and value different motorcyclists.

Instead of identifying themselves as members of motorcycle groups, eight of the ten interviewees, without prompting, referred to themselves as "bikers" at least once. In this sense, their work is also leisure: Being a motorcycle deliveryman means receiving pay for pursuing one's hobby. "That's what attracted me the most to this profession: it was a form of leisure. I already began working considering it leisure. I used to go to work; my previous profession was not this profession" (Nicolas).

Nonetheless, this does not mean that the interviewees believe that distinguishing themsel- 


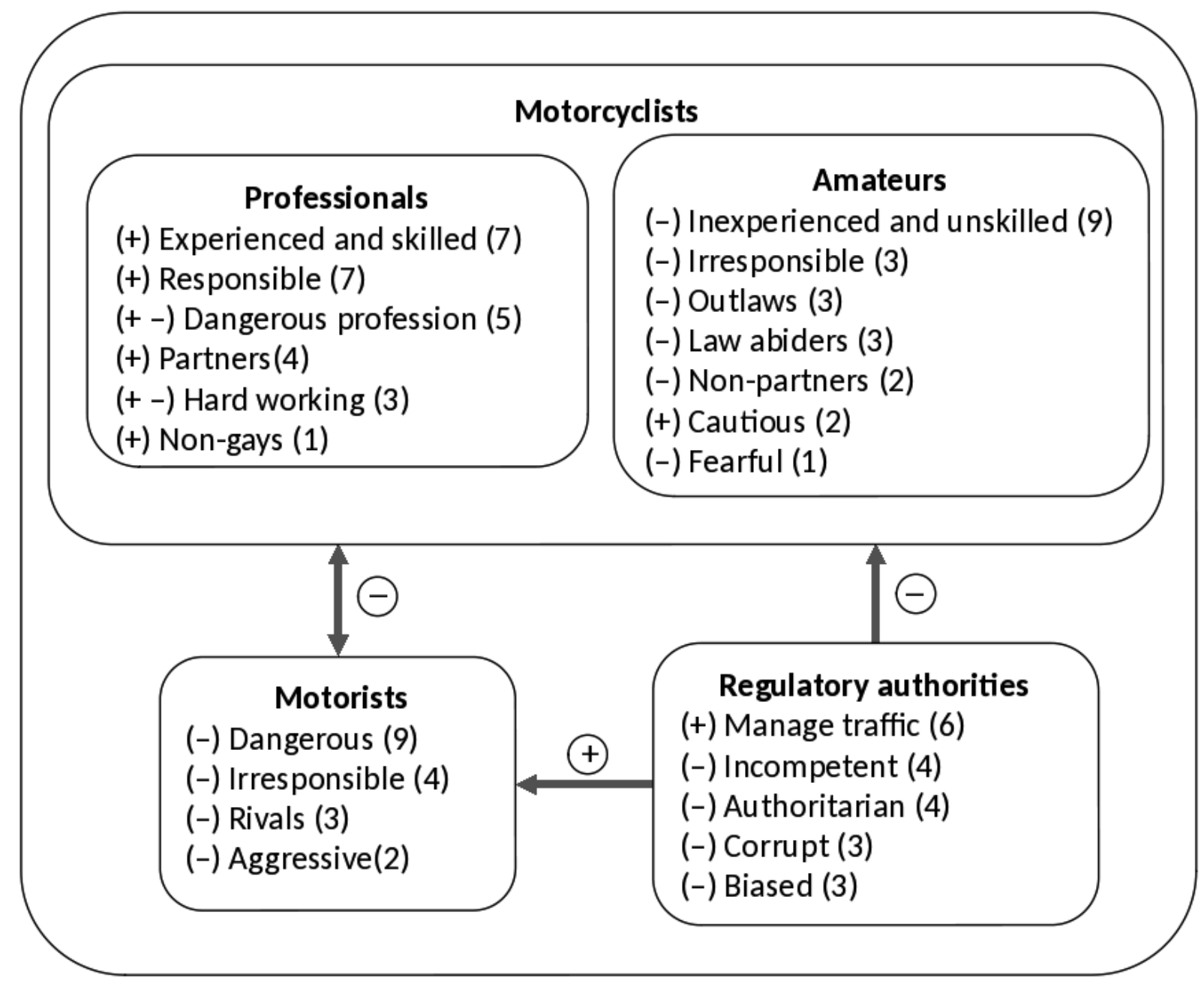

Figure 1. Characteristics and relationships attributed to groups made up of Professional Motorcyclists, Amateur Motorcyclists, Motorists and Regulatory Authorities. Each code is preceded by a plus sign or a minus sign, which indicates its positive/ negative value; the presence of both refers to an ambiguous assessment. The numbers in parentheses refer to the number of interviews in which each code is present. Arrows with plus or minus signs represent a harmonious or conflicting relationship between groups, respectively.

ves from other bikers is unimportant. For those who view motorcycling and career as two sides of the same coin, amateurism is a shortcoming. A "true biker" is one who earns a living riding a motorcycle, enjoys strong ties of solidarity, and is responsible, skillful and experienced.

In the interviewees' opinion, other people's general underrating of motorcyclists amounts to a lack of knowledge of their internal differences: "I think they choose us as scapegoats" (Marcos), that is, as recipients of characteristics that they do not possess. "It's just like the old proverb: They judge the righteous by the sinners" (Renato).

The distinction between motorcyclists is thus achieved by attributing polarized characteristics to two hierarchically categorized classes of bikers: Professional Bikers and Amateur Bikers. The interviewees' reactions to each negative characteristic attributed to bikers are quite similar: The amateur motorcyclists, the non-motoboys, are the ones who end up "tarnishing the image of those who are peaceful, working people" (Lucas).

Being skilled at riding a motorcycle is essential to being a good motorcyclist and is directly related to the rider's driving experience in traffic, for it is only through such experience that he acquires the "cunning" necessary to face this hostile environment. It is no coincidence that professional bikers are Experienced and skilled (7); and amateur bikers, Inexperienced and unskilled (9). 
Some drivers have no experience whatsoever; they're the dangerous ones. They have no cunning in traffic. The other day, a car was pressuring me... If I were one of those guys, with no experience, I'd already have crashed. (Jorge)

In addition to skillfulness, avoiding accidents also requires a greater sense of responsibility. What makes the difference is the profession: Motorcycle deliverymen are Responsible (7); and amateurs, Irresponsible (3).

It's a really big responsibility, you know what I mean? There's no other way. The guy gives you the route map, and you have to be up to it. You have to take responsibility....] do your job. (Nicolas)

Because of the wide range of reasons for people being on the road and for being a part of the motorcycling universe, solidarity among motorcyclists is also not distributed symmetrically. According to the interviewees, motoboys enjoy solid ties of brotherhood with each other, and they are each other's Partners (4), yet one cannot expect the same of amateur bikers, the Non-partners (2). "When the guy is a real motorcyclist, a guy who actually works, he sees a biker parked alongside the road, stops and checks out the situation. Yet, the other guy might or might not stop, you know?" (Natan).

Similarly, a motorcycle trunk - basic work equipment - is what distinguishes professional bikers from Outlaws (3), who belong to the amateur group. "With respect to outlaw bikers, the guy usually carries a passenger. Sometimes you use a trunk, and the guy treats you like an outlaw" (Davi).

The characteristics that professional bikers attribute to themselves and to amateur motorcyclists can thus be interpreted as being dependent on negative characteristics they believe are widely shared in relation to the group they belong to. In this sense, the irresponsibility and criminality perceived in "what they say about us" can also be found in the negative characteristics attributed to amateur motorcyclists. Although the motorcyclists often belong to the same group, their conception of two clearly distinct classes of motorcyclists facilitates their attri- bution of positive characteristics to themselves and to the group itself via the self-patronizing displacement of the threat posed by the negative characteristics.

Nonetheless, not all of the interviewees' comparative opinions demean amateur bikers. Two of them believe that amateur bikers are more Cautious (2) than bikers who Work hard (3) in a Dangerous profession (5) are. Unlike the amateur biker, however, the professional biker runs more risks precisely because he uses his ability and experience in favor of his responsibility toward his work. The same ability is responsible for minimizing the risks inherent to the profession (not the group one belongs to).

Bikers are calmer; they have more time to themselves and don't have to drive between lanes, right? They use motorcycles as a leisure activity, like going out for a ride. Motorcycle deliverymen are different: They have to ride between lanes and run traffic lights. That happens sometimes: The traffic light turns yellow, because of the limited time. (Gustavo)

Associated with greater road safety, amateur bikers end up overly subjecting themselves to traffic laws. They are Law abiders (3) and are even a bit Fearful (1). Good motorcyclists are not just responsible; they also know when to break a law and they have the courage to take risks (for their own good).

I think motorcycles have to take the lead. If you follow a bus, a car, a ... your chances of getting into an accident are much greater than if you ride between the lanes. You need to be able to see the ground; otherwise, you will get into an accident. (Davi)

Although it amounts to a road "hazard," an amateur biker's lack of experience is accompanied by greater caution, fear, and obedience of the law. There is sufficient evidence to suspect that, in the opinion of the motorcycle deliverymen we interviewed, amateur bikers are not manly enough and, precisely for that reason, are incapable of being good drivers.

Lastly, the demands of the profession are such that, according to the interviewees, they naturally repel homosexual men. After all, hete- 
rosexuality is a key element of hegemonic manliness, which is an essential trait of good bikers. A real biker is a Non-gay (1).

I was conversing recently [laughs] - it cracks me up - and I said ... "Have you ever seen a gay motorcycle deliveryman?" [laughs] I've never seen one. Well, there are closet-queen motoboys, but . . . have you ever noticed that, in this profession, gays don't want to be motoboys? (Davi)

In this scenario, motorcycle deliverymen stand out as the role model of the good biker: They are responsible, experienced and skilled, partners among themselves, and are not scared like their amateur peers are. They run many risks in their day-to-day lives, not for lack of proficiency, but for working hard in a hazardous profession, a burdensome activity that enables them both to affirm their virility through hard work and to distance themselves from examples of fragility, such as overzealous men and homosexuals. A "real biker" is a real man.

\section{Them: Motorists and Regulatory Authorities}

Up to this point, we have covered the manner in which the interviewees conceive and express motorcycling and their profession, how they differ internally and perceive the different uses and users of motorcycles. Another prime source of information concerning the manner in which standards of manliness contribute to developing the identity of professional motorcyclists is the way they compare themselves with and differentiate themselves from other male groups within the traffic context. Within this context, the incontestable risk posed by road traffic relates to both the hostility manifested by motorists and the complacency and inefficiency of traffic regulatory authorities.

When professional motorcyclists distinguish themselves from groups they consider important, the distinction between professional and amateur motorcyclists is circumstantially abandoned, and the group they belong to, bikers, becomes relatively more homogeneous. Regardless of whether motorcycling is work or a leisure activity, moving around on two wheels means getting to know oneself in an unfavorable situation in front of other men.

Motorists form a group made up of a broad diversity of individuals: drivers of taxis, cars, trucks, trailers, buses, etc. Nonetheless, all of them share the status of Rivals (3) in relation to motorcyclists. In their daily dispute for space on the road, in addition to being Aggressive (2) and Irresponsible (4), such motorists drive vehicles that are larger, more powerful and thus more Dangerous (9) than those of bikers

"They don't respect bikers very much. Even bus drivers, you gotta be nuts. Buses and trucks: you gotta get out of their way. If they're approaching you from behind, you pull over, man, and let 'em pass" (Natan).

The behavioral implications for bikers are clear: Motorists are a group that must be constantly avoided in traffic. A good motorcyclist is one who is always alert to the frequently deadly threat posed by drivers. Against the irresponsibility and violence of drivers, bikers can only rely on their own ability, experience and outstanding sense of responsibility.

For their part, regulatory authorities are a diffuse category made up of a wide range of individuals who the interviewees recognize as representative of public order: politicians, members of oversight agencies, of the police, of the judiciary, of the "government," etc. In the opinion of six interviewees, such authorities play an essential role: They Manage traffic (6), establish the laws and norms that govern the roads and highways and enforce compliance with such regulations. From this standpoint, traffic problems would be the result of disrespect for the law.

"Most accidents occur because people don't respect speed limits, road signs, the right-of-way; that's the reason. If everyone respected the speed limit and traffic signs, we wouldn't have this problem" (Gustavo).

Nonetheless, in Brazil, people's distrust of regulatory authorities obstructs their compliance with the law. Despite recognizing the importance of outside intervention, professional motorcyclists are aware of the risks it poses to their profession. Everything would be going well if regulatory authorities were not Corrupt (3). 
"Our road traffic is extremely chaotic, poorly signposted and highly makeshift, with roadways full of potholes. You see poor-quality asphalt everywhere so that the budget funds saved go to the corrupt" (Marcos).

Regulatory authorities are also considered Authoritarian (4), thus purportedly obstructing motorcycle deliverymen's right to self-determination and coercing them via fines and other penalties.

I'm not in favor of anyone forcing me to do anything... If I were to have a crazy impulse and decided to die riding my bike, I still couldn't allow myself the luxury of riding around without a safety antenna ${ }^{1}$; otherwise, I couldn't die in peace. Besides dying, I'd have to pay a fine [laughs]. (Lucas)

In addition to limiting motorcyclists' freedom and acting in their own interest, regulatory authorities are also Biased (3) in relation to resolving traffic conflicts, always favoring motorists over motorcyclists.

"[In] ninety percent of accidents, the biker gets the blame; unfortunately, he's the wrongdoer. Regardless of how much the guy doesn't want to be, when the traffic officers show up, the biker is wrong" (Renato).

To a real biker, one who knows the streets and the traffic like the back of his hand, the regulatory agent is practically a comical character: a public servant, isolated from reality in an office, transforming his fantasies into laws. For example, there are many reports of the audacity of inexperienced instructors who "know nothing about motorcycles" yet want to teach something to those who are most familiar with their own work: motoboys themselves. Regulatory authorities are indeed Incompetent (4).

I think the government . . merely uses the numbers, not seeing what needs to be done, what happens ... if motoboys have to stop working in order to take those courses that the government requires ... It just doesn't want to see. (Marcos)

Translator's note: an antenna-like device for cutting glass-coated kite stings that is required by law in Brazil.
Hence, whether because of ignorance or bad faith, regulatory authorities are the only ones who can obstruct the freedom achieved through the motorcycle as a vehicle and an occupational tool. Together, drivers' aggressiveness and regulatory authorities' interference will end up producing harmful effects in the traffic everywhere, resulting in an environment of enmity and disorder. Faced with a corrupt public system, a "true biker" (a motoboy) enjoys a high moral sense, occasionally being compelled to disobey certain erroneous laws in order to do what he knows is right.

While the interviewees admit that they face numerous traffic risks, they largely consider themselves invulnerable to them. In a context in which the high rate of motorcyclist fatalities is evident, attributing the risk to the profession or to an outside group has an acute psycho-sociological implication: The risk you run is not your own responsibility or that of your group. Attributing the danger to an outside group can thus catalyze the purging of one of the worst possible consequences of such attribution: one's own group's assimilation of a model of frailty and incompetence, that is, of an inferior model of masculinity.

On the contrary, more than just a working man subjected to a precarious, alienating situation that, in exchange for a monthly income, can cost him his life or seriously harm his health, the motoboy sees himself as a man who sidesteps death every single day and has full control of his destiny. At this point, we believe no further evidence is necessary for one to accept the fact that, in the present study, we are dealing not only with individuals striving to value themselves and their group, but also with men striving to prove their worth as men in the presence of other men.

Hence, in both cases, within both the context of professional versus amateur motorcyclists and the context of motorcyclists versus motorists and regulatory authorities, gender distinctions are the principal criterion for differentiation, a criterion that is common to the characteristics attributed to each group. Being a biker is a gendered identity. 


\section{Final Considerations}

In an aggressive, competitive social environment such as traffic, which, according to the interviewees, is managed by incompetent, authoritarian, corrupt regulatory authorities, motorcycle deliverymen feel they are threatened by irresponsible, aggressive drivers, with whom they maintain a mutual relationship of rivalry. The result is a comparative context in which motorcyclists, although suffering inferior status in relation to other traffic players, are the only ones that, according to them, are characterized by acceptable traits and behaviors.

Within this more general context, the categorization of the various actors involved in traffic is similar to the model proposed by Tajfel $(1982,1983)$. As aforementioned, the "aggressiveness" that, in the opinion of the interviewees, characterizes traffic is not randomly manifested between isolated individuals, but rather between motorcyclists and motorists (with the connivance of regulatory agents). We are thus dealing with an intergroup conflict in which the motoboys that were interviewed feel that the manner in which they are treated is determined, not by their idiosyncratic characteristics, but by the fact that they belong to a minority group. From this standpoint, the individuals' social identities are highlighted, the similarities among members of the same group are overemphasized and, at the same time, the similarities between members of different groups are minimized. Motorists and regulatory authorities are presented as non-bikers, as groups of individuals that are characterized by negative traits in comparison with the responsible, skilled, dedicated members of the inner group. Consequently, the effects of attributing stereotypes and self-stereotypes increase.

Nonetheless, although both professional and amateur bikers belong to the world of motorcycling, the distinguishing characteristics the former attribute to the latter have strategic value because they limit the negative traits attributed to motorcyclists in general to a subgroup to which they do not belong. If people believe that motorcycle deliverymen are responsible for the vio- lence and chaos on the road, it is because they do not understand the differences between working people and irresponsible individuals or outlaws and they "judge the righteous by the sinners."

In this case, the image of the amateur motorcyclist is that of a man who lacks self-control, a reckless outlaw who risks his life and the lives of others. At the same time, however, it is also an image of a weak, insecure man who lacks the quick reflexes professional bikers must have in order to survive in the day-to-day traffic. He lacks the necessary experience and "cunning." Furthermore, he lacks the courage. He is thus both excessively macho, because he is impulsive and brutish, and insufficiently manly, because he is inexperienced, fearful and cautious.

The interviewees thus demonstrate that they share a common ideal, a role model characterized by male values: a competent, responsible, heterosexual, daring, fearless, independent, dominant individual. A "good biker" is not only a good driver and a hard worker, but also an exceptional man.

Although motorcycle deliverymen know they hold inferior status in the social hierarchy of traffic, the change in the criteria of comparison will enable them to increase the value of their belonging to the group. While they feel they cannot compete with other men who have greater decision-making influence and power (regulatory authorities), or with the comfort and privileges of those who drive larger, more powerful vehicles (motorists), motoboys can still surpass them in terms of their psychological proximity to a hegemonic, male ideal.

According to Tajfel (1982), in a concrete context of intergroup comparison and conflict, one is not dealing with an "autistic" valuing of one's own belonging. Instead of being gross distortions of reality aimed at self-advancement, the group distinctions made by the interviewees revealed both strategic use of identity representations and openness to the negotiation of standards, but they also involved a series of concessions. More than merely sharing a general, unrestricted self-valuing opinion of the group itself, the interviewees as a whole, in an arena 
in which they believe they can compete, seem to share a mutual preference for what really matters: the successful acquisition of masculinity.

\section{References}

Amâncio, L. (1997). Identidade social e relações intergrupais. In J. Vala \& M. B. Monteiro (Eds.), Psicologia social ( $3^{\text {rd }}$ ed., pp. 287-307). Lisboa: Fundação Calouste Gulbenkian.

Bardin, L. (2011). Análise de conteúdo (5 $5^{\text {rd }}$ ed., L. A. Reto \& A. Pinheiro, Trans.). Lisboa: Edições 70. (Original work published 1977)

Berger, M. L. (1992). The Car's Impact on the American Family. In M. Wachs \& M. Crawfor (Eds.), The car and the city: The built environment, and daily urban life (pp. 57-74). Detroit, MI: The University of Michigan Press.

Castro, M. F. (2010). Os motoboys de São Paulo e a produção de táticas e estratégias na realização das práticas cotidianas (Doctoral dissertation, Instituto de Psicologia, Universidade de São Paulo, SP, Brazil).

Connell, R. W. (1997). La organización social de la masculinidad (O. Jiménez, Trans.). In T. Valdés \& J. Olavarría (Eds.), Ediciones de las Mujeres: Vol. 24: Masculinidad/es: poder y crisis (pp. 3148). Santiago de Chile: ISIS-FLACSO.

Deschamps, J.-C., \& Moliner, P. (2009). A identidade em psicologia social: Dos processos identitários às representações sociais (L. M. E. Orth, Trans.). Petrópolis, RJ: Vozes.

Diniz, E. P. H., Assunção, A. A., \& Lima, F. P. A. (2005). Prevenção de acidentes: O reconhecimento das estratégias operatórias dos motociclistas profissionais como base para a negociação de acordo coletivo. Ciência \& Saúde Coletiva, 10(4), 905-916. doi: 10.1590/S141381232005000400014

Fernandes, H. S. (2012). A relação entre as Identidades Territoriais e a "nova urbanidade": $O$ caso das manifestações identitárias dos grupos de motociclistas em Salvador, Bahia (Master thesis, Instituto de Geociências, Universidade Federal da Bahia, Salvador, BA, Brazil).

Ferreira, F. F. (2009). Fatores de risco em acidentes envolvendo motocicletas em vias urbanas: $A$ percepção dos condutores profissionais (Master thesis, Programa de Pós-Graduação em Enge- nharia de Produção, Universidade Federal do Rio Grande do Sul, Porto Alegre, RS, Brazil).

Figliuzzi, A. (2008). Homens sobre rodas: Representações de masculinidades nas páginas da revista Quatro Rodas (Master thesis, Faculdade de Educação, Universidade Federal do Rio Grande do Sul, Porto Alegre, RS, Brazil).

Hopper, C. B., \& Moore, J. (1983). Hell on Wheels: The outlaw motorcycle gangs. Journal of American Culture, 6, 58-64. doi:10.1111/j.1542734X.1983.0602_58.x

Hopper, C. B., \& Moore, J. (1990). Women in outlaw motorcycle gangs. Journal of Contemporary Ethnography, 18(4), 363-387. doi: 10.1177/089124190018004001

Keijzer, B. (1998). El varón como factor de riesgo: masculinidad, salud mental y salud reproductiva. In E. Tuñón (Ed.), Género y salud en el Sureste de México (pp. 199-219). Villahermosa, MX: ECOSUR.

Kimmel, M. S. (1998). A produção simultânea de masculinidades hegemônicas e subalternas. Horizontes Antropológicos, 4(9), 103-117. doi: 10.1590/S0104-71831998000200007

Lara, A. A. (2007). Representação de mulher nos comerciais de automóveis: Garota é apenas equipamento opcional (Master thesis, Faculdade de Comunicação, Universidade de Brasília, DF, Brazil).

Luz, C. C. R. (2009). Sobre duas rodas: Emoções e consumo no motociclismo (Master thesis, Instituto de Filosofia e Ciências Humanas, Universidade do Estado do Rio de Janeiro, RJ, Brazil).

Matos, R. H. F. (2008). Estudo exploratório das relações de trabalho como fator de influência do comportamento humano no trânsito: Caso do motofrete (Master thesis, Faculdade de Tecnologia, Universidade de Brasília, DF, Brazil).

Olavarría, J. (2004). Masculinidades, poderes y vulnerabilidades. In A. V. Alvarez (Ed.), Chile 2003-2004: los nuevos escenarios (inter) nacionales (pp. 227-244). Santiago, Chile: FLACSO-Chile.

Paes-Machado, E., \& Riccio-Oliveira, M. A. (2009). O jogo de esconde-esconde: Trabalho perigoso e ação social defensiva entre motoboys de Salvador. Revista Brasileira de Ciências Sociais, 24(70), 91-184. doi: 10.1590/S010269092009000200006 
Rodrigues, C. S., Ladeira, R. M., Pereira, J. C., \& Paula, I. M. (Eds.). (2005). Saúde em trânsito: Pesquisa de acompanhamento de vitimas de acidentes de trânsito em Belo Horizonte. Belo Horizonte, MG: Prefeitura de Belo Horizonte.

Scharff, V. (1992). Gender, electricity, and automobility. In M. Wachs \& M. Crawfor (Eds.), The car and the city: The built environment, and daily urban life (pp. 75-85). Detroit, MI: The University of Michigan Press.

Silva, D. W., Andrade, S. M., Soares, D. A., Nunes, E. F. P. A., \& Melchior, R. (2008). Condições de trabalho e riscos no trânsito urbano na ótica de trabalhadores motociclistas. Physis [online], 18(2), 339-360. doi: 10.1590/S010373312008000200008

Silva, F. H. V. C., \& Günther, H. (2009). Psicologia do trânsito no brasil: De onde veio e para onde caminha? Temas em Psicologia, 17(1), 163-175. Retrieved from http://pepsic.bvsalud.org/scielo. php?script $=$ sci_arttext\&pid $=$ S1413-389X20090 $00100014 \& \operatorname{lng}=$ pt\&tlng $=$ pt

Souza, L. C. G. (2001). As representações sociais do carro, da velocidade e do risco em jovens (Master thesis, Instituto de Psicologia, Universidade Federal do Rio de Janeiro, RJ, Brazil).
Tajfel, H. (1982). Grupos humanos e categorias sociais: Estudos em psicologia social (Vol. 1; L. Amâncio, Trans.). Lisboa: Livros Horizonte.

Tajfel, H. (1983). Grupos humanos e categorias sociais: Estudos em psicologia social (Vol. 2; L. Amâncio, Trans.). Lisboa: Livros Horizonte.

Wachs, M. (1992). Men, women, and urban travel: The persistence of separate spheres. In M. Wachs \& M. Crawfor (Eds.), The car and the city: The built environment, and daily urban life (pp. 86-100). Detroit, MI: The University of Michigan Press.

Waiselfisz, J. J. (2013). Mapa da violência 2013: Acidentes de Trânsito e Motocicletas. Rio de Janeiro, RJ: Centro Brasileiro de Estudos Latino-Americanos.

Wolf, D. R. (1991). The rebels: A brotherhood of outlaw bikers. Toronto: University of Toronto Press. 